ISSN 2078-6441. Вісник Львівського університету. Серія географічна. 2013. Випуск 44. С. 228-234. Visnyk of the Lviv University. Series Geography. 2013. Issue 44. P. 228-234.

$631.417 .1(477.74)$

\author{
ригорій ороз \\ деський держ вний гр рний університет, \\ вул. нтелеймонівськ, 13, 65012, м. дес, кр їн
}

пектр льними метод ми визн чено генетико-геогр фічні особливості гумінових кислот грунтів середньосухостепового педоекотон . изн чено, що з пок зник ми оптичної щільності грунти смуги переходу від сухого до середнього тепу н леж ть до чорноземів південних.

лючові слов : оптичн щільність, гумінові кислоти, чорноземи південні, темно-к шт нові грунти.

ьогодні відомо, що в молекулярних структур х гумінових кислот $(\quad$ ) міститься інформ ція про специфіку процесу грунтоутворення, як відобр ж є особливості як вихідного орг нічного м тері лу, т к і умов, у яких відбув ється процес. ині вимірюв ння оптичних щільностей гумінових кислот $є$ одним із н йв жливіших прийомів грунтово-генетичних досліджень, послідовність коефіцієнтів екстинкції в ряді широтної зон льності грунтів м йже ет лонн . дн к м ло ув ги приділяють провінцільним особливостям і в ріюв нню їхніх оптичних вл стивостей у меж х грунтів одного типу (контуру, л ндш фту, к тени) т в меж х грунтового профілю, хоч в рі ція коефіцієнтів екстинкції і вплив місцевих умов можуть деколи зн чно більше вплив ти н оптичні вл стивості, ніж особливості гуміфік ції в грунт х різних типів [5, с. 178-179].

б'єктом дослідження є грунти середньосухостепового педоекотон - смуги переходу від середнього до сухого тепу в івнічно- хідному ричорномор'ї ( ре л поширення чорноземів південних з лишково- і сл бкосолонцюв тих), що простяг ється від р. р бой н з ході до ніпровсько- узького лим ну н сході. етодологічну 6 зу вивчення грунтів цієї смуги ст новлять різном нітні н укові методи, основним 3 яких є порівняльно-геогр фічний, який використ но у ході к ртогр фув ння грунтів н шести ключових ділянк х з г льною площею 1090 г, ключ-профілях т 58 опорних розріз $\mathrm{x}$.

птичну щільність гумінових кислот визн ч ли спектрофотометрично, коефіцієнти екстинкції т оптичної щільності розр ховув ли з . рловим [8, с. 101-107], т кож 3 . оном рьовою і . лотніковою [9, с. 63].

ослідженню оптичних щільностей гумінових кислот чорноземів південних т темнок шт нових грунтів присвячені пр ці . ононової, . лотнікової, . єльчикової, . оном рьової, . рлов т інших дослідників. підст ві порівняння оптичної щільності гумінових кислот, отрим ної н ми, з д ними . єльчикової т лотнікової, з зн чимо, що грунти території досліджень м ють чорноземоподібний х р ктер кривих спектр поглин ння. н ведених д них б чимо, що грунт м середньо-сухостепового

(C) ороз ., 2013 
педоекотон вл стив висок оптичн щільність, очевидно, ун слідок перев ж ння в їхньому скл ді чорних гумінових кислот. . ононовою, висок оптичн щільність гумінових кислот є пок зником зн чної конденсов ності їхнього ром тичного ядр i невеликого вмісту в їхніх молекул х бокових р дик лів, що несуть гідрофільні групи [1, с. 241]. чевидно, умови грунтоутворення н території дослідження, зокрем , обмежен кількість оп дів у літній період і нейтр льн бо сл бколужн ре кція грунтового розчину, сприяють утворенню скл дних форм гумінових кислот.

роте оптичн щільність грунтів, що розт шов ні н верхніх ч стин х схилів, $\epsilon$ нижчою. е свідчить про вищий вміст бурих гумінових кислот, що н ближ є ці грунти до темно-к шт нових. кож причиною зниження оптичної щільності цих грунтів може бути вміст молодших , що м ють спрощену будову бо продукти відшеплення від них, які близькі 3 вл стивостями до фульвокислот. ростежується й зменшення оптичної щільності із півночі н південь т 3 х ходу н схід (див. т блицю). е пояснюють збільшенням вмісту бурих гумінових кислот у темно-к шт нових грунт х, н шо зверт в ув гу . рлов [6, с. 278-279; 7, с. 9]. жливим є й порівняльне зіст влення зн чень оптичної щільності усього грунтового профілю у вигляді профільної кривої. прикл д, у нижній ч стині грунтового профілю оптичн щільність помітно знижується вн слідок того, що, імовірно, сюди мігрують із верхніх горизонтів л більніші спрощеної будови і продукти відщеплення від них, які близькі з вл стивостями до фульвокислот. изькі пок зники оптичної щільності у нижній ч стині профілю досліджув них грунтів свідч ть про їхній генетичний зв’язок з фульвокислот ми й про можливість існув ння між ними перехідних форм (див. рис. 1).

ок Зники оптичних вл стивостей грунтів

\begin{tabular}{|c|c|c|c|c|c|}
\hline \multirow[b]{2}{*}{ ОК зНИк } & \multirow{2}{*}{$\begin{array}{c}\text { орноземи } \\
\text { південні не } \\
\text { солонцю- } \\
\text { в ті }\end{array}$} & \multicolumn{3}{|c|}{$\begin{array}{c}\text { орноземи південні з лишково- і сл бко- } \\
\text { солонцюв ті }\end{array}$} & \multirow{2}{*}{$\begin{array}{c}\text { емно- } \\
\text { к шт нові } \\
\text { сл бко- } \\
\text { солонцю- } \\
\text { в ті } \\
\text { грунти } \\
\end{array}$} \\
\hline & & рівнин & $\begin{array}{c}\text { верхня } \\
\text { ч стин схилу }\end{array}$ & $\begin{array}{c}\text { нижня } \\
\text { ч стин схилу }\end{array}$ & \\
\hline $430^{2}$ & 24,589 & $\frac{20,150}{17,515-24,795}$ & $\frac{17,639}{15,728-20,140}$ & $\frac{21,553}{17,882-25,265}$ & 16,132 \\
\hline $\mathrm{E}_{485}{ }^{3}$ & 20,514 & $\frac{16,106}{13,662-20,353}$ & $\frac{13,050}{12,125-16,581}$ & $\frac{17,235}{14,206-20,471}$ & 12,963 \\
\hline $\mathrm{E}_{690}{ }^{4}$ & 7,721 & $\frac{4,840}{3,735-6,338}$ & $2 \frac{3,367}{2,257-4,985}$ & $\frac{5,785}{4,243-8,029}$ & 3,412 \\
\hline $4^{0,0015}$ & 0,151 & $\frac{0,119}{0,100-0,149}$ & $\frac{0,096}{0,089-0,122}$ & $0, \frac{0,127}{04-0,150}$ & 0,090 \\
\hline $\mathrm{E}_{4} / \mathrm{E}_{6}$ & 2,657 & $\frac{3,341}{3,011-3,640}$ & $3, \frac{4,001}{31-5,381}$ & $\frac{3,034}{2,458-3,499}$ & 4,116 \\
\hline ст 6 & 20,543 & $\frac{10,871}{7,725-14,569}$ & $\frac{8,232}{5,647-11,170}$ & $\frac{12,330}{9,097-17,601}$ & 5,957 \\
\hline 7 & 5,87 & $\frac{4,69}{3,63-6,55}$ & $\frac{3,45}{2,47-4,30}$ & $\frac{5,29}{3,44-6,81}$ & 3,99 \\
\hline
\end{tabular}

р и м і тк и : ${ }^{1}$ исельник - середнє зн чення, зн менник - гр ничні зн чення; ${ }^{2}$ оефіцієнт оптичної щільності з довжини хвилі $430 \mathrm{Hм;}{ }^{3}$ оефіцієнт оптичної шільності з довжини хвилі 485 нм; ${ }^{4}$ оефіцієнт оптичної щільності з довжини хвилі $690 \mathrm{Hм;}{ }^{5}$ оефіцієнт оптичної щільності з довжини хвилі 485 нм концентр ції розчину 1 мг/100 мл, 3 довжини кювети $1 \mathrm{cm;}{ }^{6}$ ок зник якості і ст більності гумусу; 7 ок зник гуміфік ції. 

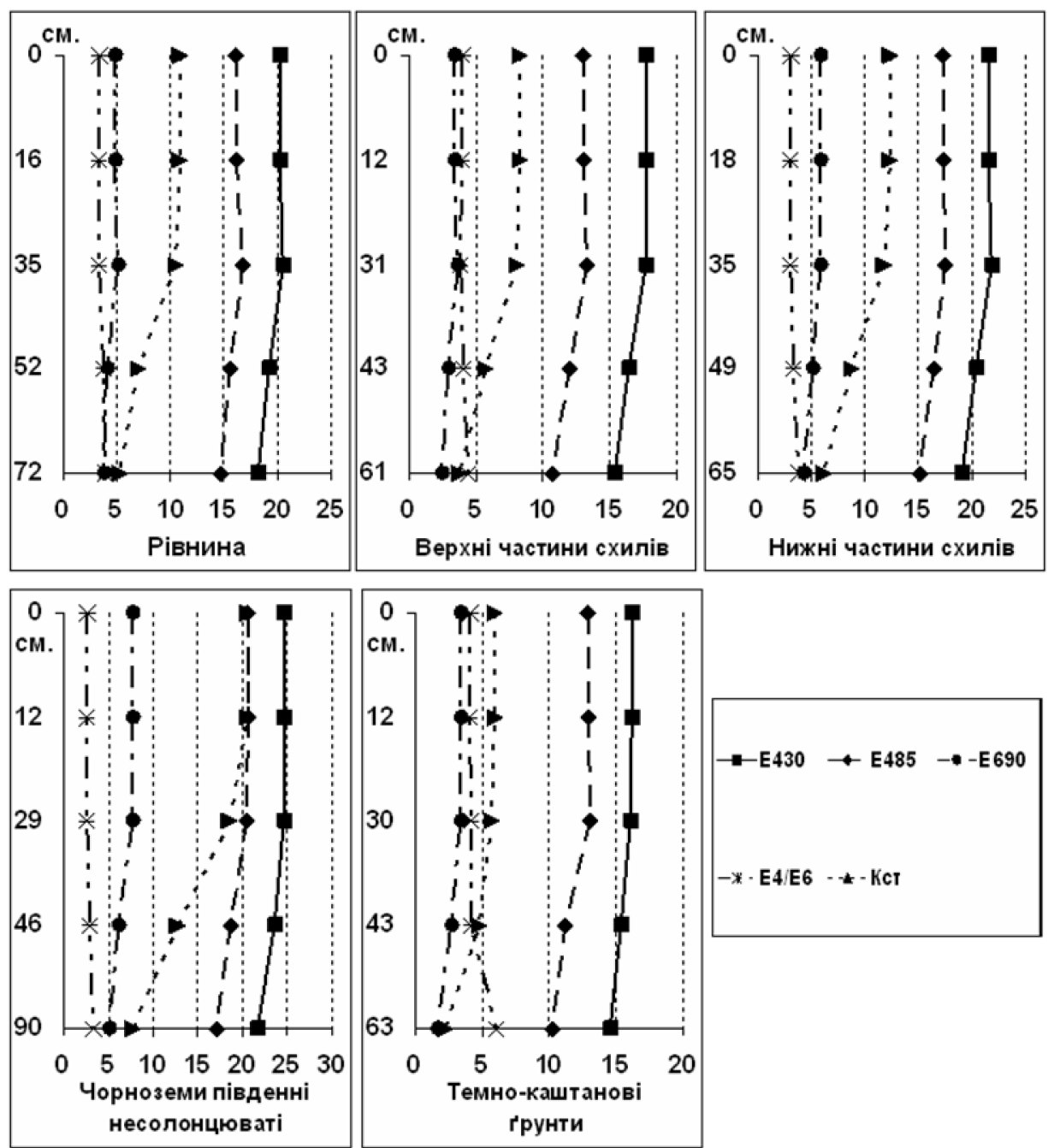

ис. 1. рофільний перерозподіл оптичних вл стивостей гумінових кислот грунтів: 430 - коефіцієнт оптичної щільності з довжини хвилі 430 нм; 485 - коефіцієнт оптичної щільності з довжини хвилі 485 нм; 690 - коефіцієнт оптичної щільності з довжини хвилі 690 нм; ст - пок зник якості і ст більності гумусу.

кож особливо інформ тивним є зіст влення х р ктеру кривих спектрів поглин ння грунтів різних рівнів педотопок тен території досліджень. грунт х вододілів і нижніх ч стин схилів 3 н йбільшою оптичною щільністю криві спектрів поглин ння м ють пологіший н хил, в грунт х верхніх ч стин схилів ці криві є дещо крутішими, що свідчить про більший вміст бурих гумінових кислот. сі спектри поглин ння не м ють ст нд ртного безперервного пл вного проходження. фіксов но н явність невеликих м ксимумів у ділянці 430-485 нм (для грунтів нижніх ч стин схилів і 
вододілів) і 485 нм (для грунтів верхніх ч стин схилів). е можн пояснити перев ж нням у скл ді мікрофлори зелених і синьозелених водоростей, поч ток м ксимуму в синьо-зеленій ч стині спектр свідчить про вищий вміст водоростей цього типу в грунт х пл корів і нижніх ч стин схилів [3, с. 63-72], що н ближ є їх до чорноземів південних (див. рис. 2).

ля порівняльної х р ктеристики оптичних вл стивостей т кож використовують зіст влення коефіцієнтів оптичної щільності (екстинції) бо інтенсивності поглин ння світл ( ) з довжин хвиль 485 і 690 нм (коефіцієнт $з$ бвленості), що можн прийняти як пок зник ступеня конденсов ності ром тичного ядр й ліф тичних структур. ироке відношення цих зн чень свідчить про перев ж ння в молекул х ліф тичних груп. н ведених д них б чимо, що н йширше співвідношення 485 до 690 простежується в грунт х верхніх ч стин схилів і $є$ пок зником сл бшої конденсов ності ром тичного ядр гумінових кислот цих грунтів вн слідок умов, створених недост тнім зволоженням.

ужче співвідношення коефіцієнтів оптичної щільності, що з фіксов но в грунтів вододілів і нижніх ч стин схилів, можн пояснити глибшими й інтенсивнішими процес ми гуміфік ції. меншення коефіцієнтів з б рвленості у грунт х вододілів і нижніх ч стин схилів з свідчує зрост ння "зрілості" цих грунтів, ліпшу структуров ність їхніх молекул, вищі зн чення цих пок зників у грунт х верхніх ч стин схилів пояснюють новоутворенням менш “зрілих” . кож виявлено чітку з кономірність збільшення відношення 485 до 690 із півночі н південь т в широтному простяг нні в н прямі переходу від чорноземів південних до темно-к шт нових грунтів [4, с. 160-165]. оефіцієнт кольоровості (відношення 485 до 690 ) т кож можн використовув ти для ді гностики типової н лежності грунту [2, с. 88]. цим пок зником грунти середньосухостепового педоекотон н леж ть до чорноземів південних.

еоднозн чний і профільний розподіл коефіцієнтів з б рвленості в досліджув них грунт х. г льною є тенденція до поступового збільшення цього пок зник вниз по профілю, проте в сл бкоксероморфних сл бкоеродов них чорнозем х південних і темнок шт нових грунт х це відбув ється різкіше порівняно з іншими грунтовими відмін ми. оясненням цього може бути процес гідролітичного відщеплення від м кромолекул винесення вниз по профілю більш л більних бічних л нцюгів у р зі посилення елюві льних умов, ун слідок прояву солонцевого процесу. кож простежується зменшення коефіцієнт з б рвленості в нижніх ч стин х деяких грунтів (див. рис. 1). кий ефект можн пояснити н явністю великої кількості ді томових водоростей, які виділяють природні орг нічні пігменти к ротиноїди червоного кольору, що спричиняє збільшення 690 і, відповідно, коефіцієнт з б рвленості [3, с. 63-72].

ля порівняльної х р ктеристики гумусових речовин різного походження широко використовують коефіцієнти рівняння угер - мберт - ep ( -величини з концентр ції 0,001 \%, довжини кювети 1 см і довжини хвилі 465 нм), які м ло змінюються в меж х одного типу і м ють близькі зн чення для споріднених з генезою грунтів.

м тері л ми досліджень окремих н уковців зн чення $4^{0,001}$ для чорноземів південних колив ються від 0,113 до 0,131, для темно-к шт нових грунтів - у меж х 0,067-0,089 [6, с. $217 ; 8$, с. 113]. н чення цього пок зник в досліджув них грунт х колив ються в меж х 0,089-0,151, що д $є$ підст ви з числяти їх, без винятку, до чорноземів південних. меншення $4^{0,001}$ у сл бкоксероморфних сл бкоеродов них грунт х т в широтному і меридіон льному простяг нні, як 3 зн чено вище, корелюють з пок зником конденсов ності ром тичного ядр (див. т блицю). 

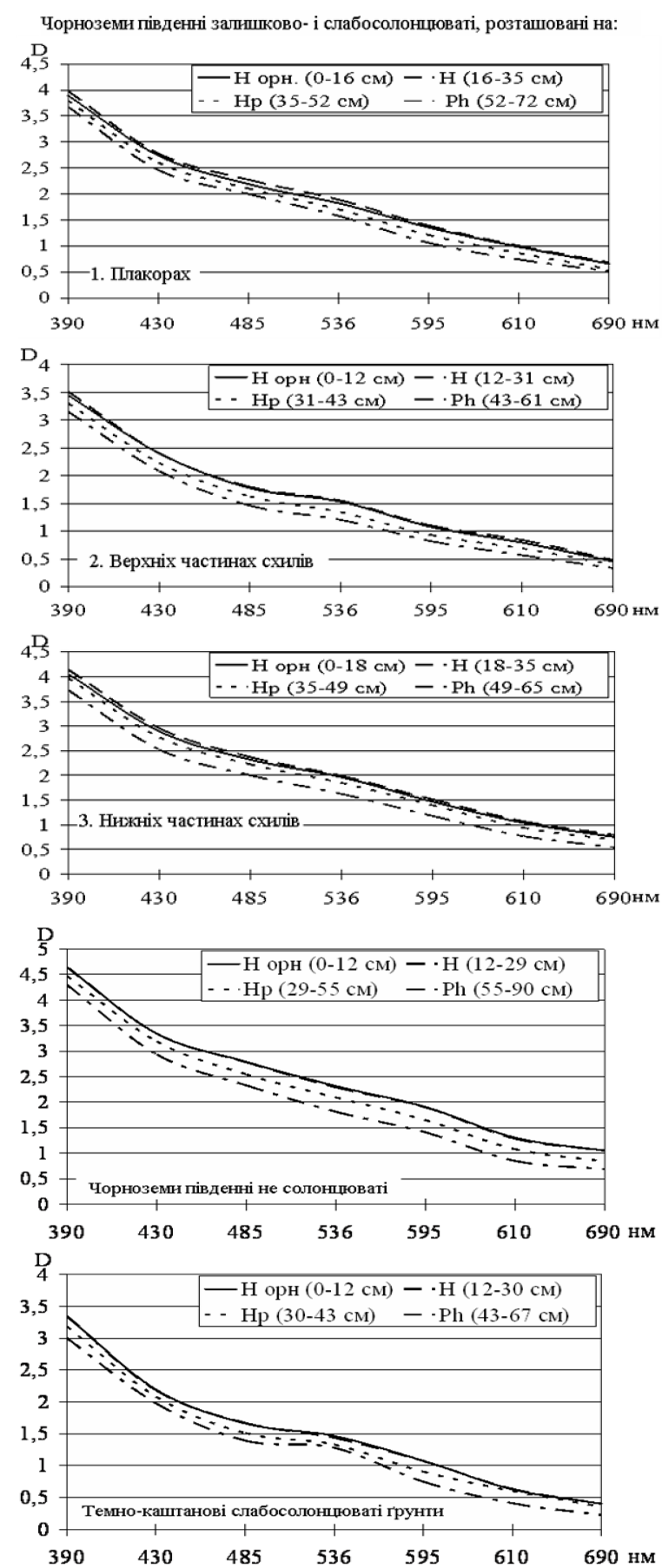

ис. 2. пектри поглин ння гум тів н трію досліджув них грунтів. 
роте $4^{0,001} €$ не дост тньо інформ тивною, тому в систему пок зників гумусового ст ну грунтів з рекоменд цією . рлов [7, с. 15-16] уведено пок зник гуміфік ції ( ), який одноч сно вр ховує кількість т їхню якість і який визн ч ють 3 формулою

де гк-ч стк вуглецю в \% до з г

$$
={ }_{2 \kappa} \times 4^{0,001},
$$

цим пок зником досліджув ні грунти м ють високий т дуже високий ступінь гуміфік ції, що х р ктеризує їх як чорноземи. иявлено зн чне зменшення в темно$\mathrm{K}$ шт нових грунт $\mathrm{x}$ T грунт $\mathrm{x}$ верхніх ч стин схилів, що свідчить про зниження темпів гуміфік ції, очевидно, вн слідок недост тнього зволоження $\mathrm{T}$ зниження ктивності мікроорг нізмів (див. т блицю).

е одним в жливим критерієм оптичних вл стивостей є пок зник якості й ст більності гумусу, з пропонов ний . ябініним i . ябініною, який розр ховують 3 формулою

$$
\text { ст }=\frac{E 430}{E 485 / E 690} \times \frac{2 \kappa}{\phi \kappa} \text {. }
$$

л бкоксероморфні сл бкоеродов ні грунти верхніх ч стин схилів м ють н 6 г то менш якісний і ст більний гумус, що свідчить про їхній перехідний ст тус від темнок шт нових грунтів до чорноземів південних. кож $\mathrm{x} p$ ктерним $\epsilon$ поступове 3 кономірне зменшення пок зник якості т ст більності гумусу з півночі н південь т з 3 ходу н схід. ю з кономірність пояснюють збільшенням вмісту бурих гумінових кислот, т кож зменшенням конденсов ності їхнього ром тичного ядр в міру переходу досліджув них грунтів від чорноземів південних до темно-к шт нових грунтів. пецифічним є змін пок зник якості й ст більності гумусу вниз по профілю грунтів. прикл д, у грунт х верхніх ч стин схилів т темно-к шт нових грунт х цей пок зник із глибиною поступово зменшується. одноч с у чорнозем х південних т грунт $\mathrm{x}$ інших рівнів місцевих педотопок тен простежується різкий перехід між горизонт ми i $\mathrm{p}$ т зн чніш под льш змін цього пок зник вниз по профілю (див. рис. 1). е можн пояснити утворенням у сл бкоеродов них грунт х молодих гумінових кислот (з мість змитих униз по схилу), т кож мігр цією із верхніх горизонтів більш л більних спрощеної будови і продуктів відщеплення від них, які близькі з вл стивостями до фульвокислот.

тже, 3 оптичними вл стивостями гумінових кислот грунти смуги переходу від сухого до середнього тепу н леж ть до чорноземів південних. птичн щільність гумінових кислот грунтів середньосухостепового педоекотон з лежить від лок льних екологогенетичних умов грунтоутворення. вододіл $\mathrm{x}$ i нижніх ч стин x схилів 3 умов підвищеного зволоження формуються гумінові кислоти з вищим ступенем конденс ції ядр , н верхніх ч стин х схилів в умов х підвищеного ксероморфізму т еродов ності утворюються більш дисперсні гумінові кислоти, що м ють сл бку конденсов ність.

\section{СПИСОК ВИКОРИСТАНОЇ ЛІТЕРАТУРИ}

1. ононов . . рг ническое вещество почвы. го природ, свойств и методы изучения / . . ононов . . . зд-во , 1963. - 316 с.

2. остенко . . орівняльний н ліз пок зників гумусного ст ну, що використовуються як ді гностичні озн ки при грунтових обстеженнях / . . остенко // існик 
. ер. рунтозн вство, грохімія, землеробство, лісове господ рство. 2008. - № 2. - . 84-89.

3. узяхметов . . одоросли зон льных почв тепи и есостепи / . . узяхметов // очвоведение. - 1991. - № 9. - . 63-72.

4. ороз . . рунти середньо-сухостепового педоекотону івнічно- хідного ричорномор'я : моногр фія / . . ороз, . . их йлюк. - ьвів : , 2011. $184 \mathrm{c}$.

5. рлов . . у умусовые кислоты почв и общ я теория гумифик ции / . . р рлов. . : зд-во оск. ун-т , 1990. - 332 с.

6. рлов . . имия почв : учебник / . . рлов. - . : зд-во оск. ун-т , 1985. $376 \mathrm{c}$.

7. рлов . . рг ническое вещество почв оссийской едер ции / . . рлов, . . ирюков , . . ух нов . - . : ук , 1996. - 256 с.

8. рлов . . р ктикум по биохимии гумус / . . рлов, . . ришин, . . рошичев . - . : зд-во оск. ун-т , 1969. - 158 с.

9. оном рев . . етодические ук з ния по определению содерж ния и сост в гумус в почв х / . . оном рев , . . лотников . - . [ .и.], 1975. - 105 с.

m ття:н дійшл до ред кцї̈ 18.04.2013

доопр иьов н 20.05.2013

прийнят до друку 17.06.2013

\title{
SPECTRAL CHARACTERIZATION OF HUMIC ACIDS IN SOILS OF MEDIUM-DRY STEPPE PEDOEKOTON OF NORTH-WESTERN PRICHERNOMORYA
}

\section{Grigoriy Moroz}

\author{
Odesa State Agrarian University, \\ Panteleymonovska St., 13, UA - 65012, Odesa, Ukraine
}

Spectral methods established genetic and geographic characteristics of humic acids in soils of medium-dry Steppe pedoekoton. It was determined that in terms of the optical density of the soil of transition from dry to medium Steppe are southern chernozems.

Key words: optical density, humic acid, southern chernozems, dark kastanozems.

\author{
ригорий ороз \\ десский госуд рственный гр рный университет, \\ ул. нтелеймоновск я, 13, 65012, г. десс, кр ин
}

пектр льными метод ми уст новлено генетико-геогр фические особенности гуминовых кислот почв средне-сухостепного педоэкотон. пределено, что по пок з телям оптической плотности почвы полосы переход от сухой до средней тепи относятся к чернозем м южным.

лючевые слов : оптическ я плотность, гуминовые кислоты, черноземы южные, темнок шт новые почвы. 